Revue Française de Civilisation Britannique

\title{
Can the Anglo-Scottish Union Survive Brexit?
}

L'Union anglo-écossaise peut-elle survivre au Brexit?

\section{Michael Keating}

\section{(2) OpenEdition}

\section{Journals}

Electronic version

URL: http://journals.openedition.org/rfcb/5039

DOI: $10.4000 /$ rfcb. 5039

ISSN: 2429-4373

Publisher

CRECIB - Centre de recherche et d'études en civilisation britannique

\section{Electronic reference}

Michael Keating, "Can the Anglo-Scottish Union Survive Brexit? », Revue Française de Civilisation

Britannique [Online], XXIV-4 | 2019, Online since 25 November 2019, connection on 27 November 2019.

URL : http://journals.openedition.org/rfcb/5039 ; DOI : 10.4000/rfcb.5039

This text was automatically generated on 27 November 2019.

\section{(c) $($ ) $\odot$ (8Y NO}

Revue française de civilisation britannique est mis à disposition selon les termes de la licence Creative Commons Attribution - Pas d'Utilisation Commerciale - Pas de Modification 4.0 International. 


\title{
Can the Anglo-Scottish Union Survive Brexit?
}

\author{
L'Union anglo-écossaise peut-elle survivre au Brexit?
}

Michael Keating

\section{The Scottish Settlement}

1 Among the foreign observers of Scotland's peculiar political and constitutional status, none was more acute than Jacques Leruez. His book L'Écosse. Une Nation sans État introduced French readers to the idea that nation and state are distinct concepts and, in the United Kingdom, different political realities. In a series of publications over the years, he explored the nature of the relationship of Scotland to the wider British state and the complex meanings of union as multinational compromise. As a student of territorial politics and statecraft, he was able to trace the multiple ways - economic, social and political - in which Scotland was integrated, without being assimilated, into the wider state. British unionism was very different from French Jacobinism and could accept differentiation in culture, education, law and social policies. The one thing it could never concede was the sovereignty of the Westminster Parliament. For a century, this meant that British governments would not bow to demands for home rule or devolution, fearing that this could lead to federalism and erosion of parliamentary sovereignty or even to secession.

2 At the end of the twentieth century, this obstacle was removed as the Labour Government set up devolved legislatures in Scotland, Wales and Northern Ireland. The sovereignty question was dealt with in a summary clause asserting that none of this affected the union or the right of the Westminster Parliament to legislate in all parts of the country. There followed a convention (the Sewel Convention) stating that it would not "normally" do so. Of course, many people in Scotland did not accept this interpretation, insisting that Scotland had its own tradition of sovereignty, that the Acts of Union did not mean that the English tradition of sovereignty had passed to the new Parliament of Great Britain, and that the devolution referendum of 1997 was an act 
of self-determination. In true British fashion, however, people were left to believe different things and relations between the two parliaments were generally cooperative, even when the Scottish National Party (SNP) was in power in Holyrood and Labour and then the Conservatives ruled at Westminster.

3 A critical factor in this was membership of the European Union and of the European Convention on Human Rights (ECHR) (under the Council of Europe), which have transformed the meaning of sovereignty and statehood in Europe. As sovereignty is divided and shared in Europe, it provides a discursive space for ideas of postsovereignty, which many nationalist and regionalist movements in Europe have adopted. ${ }^{1}$ Post-sovereignty does not mean that sovereignty has disappeared but that it has been transformed and is no longer monolithic and located only in the nation-state. The Northern Ireland settlement explicitly invites citizens to choose whichever combination of identities (Irish, British, Northern Irish, European) they prefer and gives these institutional expression. Most Scots, rather than being torn between British and Scottish identities, combine these in varying proportions. The SNP's embrace of Europe from the mid-1980s was a recognition that independence is not isolation but rather a change in the complex web of interdependencies in which the nation is located. Radical visions of a Europe of the (small) Nations or Europe of the Regions may have come to little, but nationalities movements in Europe do see it as a framework for greater autonomy and protagonism. During the independence referendum campaign of 2014, both sides were committed to Europe, differing only on the best way to stay in it. Unionists argued that an independent Scotland would be excluded from the EU, while nationalists warned that, without independence, Scotland risked being dragged out of the EU by a Eurosceptic England. With the consensus on Europe, the argument then came down to managing the various unions. SNP leader Alex Salmond even argued that Scotland was currently in six unions - political, monarchical, monetary, defence, European, and social - and proposed withdrawing only from the first.

4 Europe provided an economic framework for independence, by guaranteeing free trade and free movement. The Single Market allowed a more generous measure of devolution in economic matters than would have otherwise been possible, as it also secured the internal market of the United Kingdom. Industrial policy, aid to industry, agriculture, fisheries and the environment were all devolved to Scotland, within the scope of EU law, which itself was directly applicable in Scotland. The only role for the UK in these fields was to secure a common negotiating position in the Council of the European Union.

5 The EU and the ECHR ensured a common regime of rights not only across the EU but within the UK. This is of vital importance in Northern Ireland and Scotland, as it separates the question of human rights from citizenship and identity. That is crucial in territories where substantial parts of the population do not identify as British but where equality of rights is important. ECHR rulings, whether by domestic courts or the European Court of Human Rights, are directly applicable in devolved fields in Scotland, Wales and Northern Ireland. In reserved fields and in England, on the other hand, they do not bind Parliament and the courts can only bring breaches of the convention to its attention.

6 Europe also serves to lower the importance of borders, so helping to bring together the two parts of Ireland without changing their constitutional status. It also eases crossborder issues between England and Scotland and, in the case of Scottish independence, 
would have prevented the emergence of a hard border, assuming that both states remained in the EU.

7 A central concern of supporters of Brexit is to reassert the sovereignty of the UK Parliament, to "bring back control". According to them, there is a fundamental contradiction between the European project, with its supranational pretentions, and the British constitution, rooted in the unassailable supremacy of the unitary Parliament. In Scotland, however, a different conception of the state prevails, according to which the United Kingdom is a plurinational union of nations, with no single people (demos) and no shared aim or end-point (telos). It is open to multiple interpretations, which co-exist in practice if not in theory and are constantly negotiated. Sovereignty is not settled but constantly questioned. For some the union is about economics, while others stress history, common sentiment or shared welfare. Understood in this sense, there is a fundamental compatibility or 'goodness of fit' between the UK constitutional order and that of Europe, which is based precisely on these ideas and has survived by not defining them too rigidly.

8 Neither the UK or the EU is a federation but they do share key federal principles. British devolution has evolved over twenty years as the institutions have matured. Northern Ireland has its own dynamics and the settlement has experienced serial crises. Scotland has gained more powers, most recently over taxation and aspects of welfare. The National Assembly for Wales has followed Scotland in gaining legislative powers and more competences. In the final days of the Scottish referendum campaign of 2014, former Prime Minister Gordon Brown rallied the unionist parties to promise more powers, calling for the UK to be as much like a federal system as was possible within the British constitution. There followed the Smith Commission and the Scotland Act (2016), which stipulated that the Scottish Parliament was a permanent feature of the constitution, which could be abolished only by referendum of the Scottish people, and put the Sewel Convention into law. Of course, if the Westminster Parliament is still sovereign, it is not bound by this Act but the move did appear to be a federalizing one and it was understood that Westminster was committing itself to legislative restraint.

\section{Scotland and Europe}

During the 1970s, Scotland was comparatively Eurosceptic. In the 1975 referendum on continued membership of the European Communities, it voted to remain by a smaller majority than did England. Both the Labour and Scottish National parties were largely opposed to the EC. In the mid-1980s, both Labour and the SNP changed positions and committed themselves to membership of the European Union. For the SNP, Europe provided a framework for independence, rebutted charges of "separatism" and offered guarantees of market access. Some nationalists accepted the full implications of Europe, that an independent Scotland would not be fully sovereign. ${ }^{2}$ Others were more wary, favouring an intergovernmental Europe of the Nations. From this point, Scots started to look on Europe less sceptically than did the English, a reverse of the position in the 1970s. This was not, however, because nationalist voters bought the argument about independence in Europe. There was no correlation whatever between views on independence and on Europe. ${ }^{3}$ Hard-line nationalists in Scotland, which includes those who want complete and immediate independence and those British nationalists who would do away with the Scottish Parliament (a much smaller number) were rather 
Eurosceptic. In the middle of both the nationalist-unionist and Europhile-Eurosceptic spectra, on the other hand, there was a strong correlation between supporting more devolution and moderate pro-Europeanism. These are the consistently postsovereigntist voters, found in all the parties. SNP voters were not particularly proEuropean and less so than Labour voters. Survey evidence suggests that, in England, support for Brexit is strongly related to feeling English rather than British. In Scotland, national identity has no such effect.

A notable feature of Scottish politics is the low salience of immigration and European free movement, compared with England. Surveys have shown that Scottish voters are not particularly pro-immigration but all parties in the Scottish Parliament have framed immigration as a demographic and economic issue, a vital means to sustain Scotland's population rather than a threat. This has served to contain one of the main drivers of Brexit sentiment.

11 These factors ensured that, in the 2016 Brexit referendum, while England and Wales voted narrowly to leave the EU, Scotland voted by a large margin to remain, with remain majorities across all parts of the country and across all parties.

Table 1. Percentage Vote in EU referendum

\begin{tabular}{|l|l|l|}
\hline & Leave & Remain \\
\hline UK & 52 & 48 \\
\hline England & 53 & 47 \\
\hline Scotland & 38 & 62 \\
\hline Wales & 53 & 47 \\
\hline Northern Ireland & 44 & 56 \\
\hline
\end{tabular}

It was immediately apparent that, with Northern Ireland also voting to remain (but divided between the two communities), Brexit posed a serious challenge to the territorial constitution of the United Kingdom. What was less clear was how this could work out. We can discuss this according to three scenarios, which have yet to play out fully. One is recentralization as the UK reconstitutes itself as a unitary state after Brexit. Another is disintegration, as the Scotland and Northern Ireland remain in the EU. A third is reconfiguration as the various nations renegotiate their places in both unions.

\section{Recentralization}

There have been a number of signs that Brexit could entail a recentralization of the state and a reversal of the federalizing trend that has prevailed since 1999. The first was the insistence by the UK Government, without consulting the devolved nations, that the whole state would withdraw. As ministers constantly repeated, this was a decision by "the British people", implying a unitary demos that had spoken as one. They 
had earlier rejected suggestions that Brexit might require concurrent majorities across the UK nations.

A second instance was the case in the Supreme Court brought by Gina Miller concerning whether the UK Government needed the consent of Parliament to activate Article 50 of the EU treaty, to begin the withdrawal process. The position of the UK Government was that triggering Article 50 did not require parliamentary approval at all but, as "foreign policy", could be done under prerogative powers. The Scottish Government joined the action, claiming that it would also trigger the need for legislative consent under the Sewel Convention, as Brexit entailed changing their devolution settlements (by removing the application of EU law). The UK Supreme Court (2017) ruled that the UK Government did indeed need parliamentary approval but not that of the devolved legislatures. ${ }^{4}$ Rather than ruling on the narrow ground that EU relations were a reserved matter and thus not subject to the Sewel Convention, the Court added that Sewel was a mere "political" convention having no binding force in any circumstances. At a stroke it thus emptied the efforts in 2016 and 2017 to entrench it, and undermined a pillar of the devolution settlement. In fact, the Supreme Court declined to enter into a constitutional argument, treating parliamentary sovereignty as a simple fact rather than a complex concept that might have to be reconsidered in the light of devolution.

15 A third instance concerns the negotiations for withdrawal. The UK Government took the position that this was a matter for it alone that the devolved bodies would only be consulted along with other stakeholders. This differed from the position in normal EU negotiations where matters touching on devolved competences are discussed in an intergovernmental forum, the Joint Ministerial Committee. Eventually, the UK Government agreed to establish a Joint Ministerial Committee (European Negotiations) but this did not have a substantive role in the negotiations themselves. It did not debate the main issues in advance of European negotiations and Scottish ministers complained that they were not informed in time of upcoming issues or given the requisite papers on time. On the other hand, this may suit the political purposes of the Scottish Government which was opposed to Brexit and not necessarily interested in helping it to happen.

16 The fourth issue concerns those competences that are devolved to Scotland but subject to European law. Agriculture, fisheries, environment, regional economic development and, in Scotland and Northern Ireland, large parts of Justice and Home Affairs competence are not reserved to Westminster. This means that, unless the devolution statutes themselves were amended, these competences would after Brexit revert directly to Scotland, Wales and Northern Ireland. Only in respect of England would they come back to Westminster.

17 Repatriation is not, however, clear cut. Regulation and support for agriculture and fisheries are devolved, but not trade. Whatever trade deals the UK signs with the UK or others will include rules on agricultural support, as would falling back on World Trade Organization rules. There is also the fact the EU framework is responsible for maintaining a single market, including fair competition and regulatory harmonization, within the UK itself. Environmental policies have external effects that need to be managed in common.

18 The UK Government's initial interpretation was that, currently, the devolved governments "are responsible for implementing the common policy frameworks set by 
the EU" rather than making policy. Taking back the powers would thus not reduce their ability to take decisions. Moreover, "when the UK leaves the EU, the powers which the EU currently exercises in relation to the common frameworks will return to the UK". ${ }^{5}$

This interpretation was strongly disputed by all the devolved administrations who argued that after Brexit the current frameworks will cease to exist as they are the product of EU law and there is no provision for them in UK law. They did come to accept that common UK frameworks might be needed but not that this would justify Westminster taking back the competences.

The initial EU Withdrawal Bill proposed that all the relevant powers would come under the heading of "retained EU law" and come back to Westminster. In due course, some of them could be "released" back to the devolved legislatures. In a rare show of unity, all parties in the Scottish Parliament refused to give legislative consent (as did the Welsh Government) and the UK Government was forced to retreat. Amendments were introduced providing that only selected competences would be taken back to Westminster and they would be released after a maximum of seven years. The reservation of powers would be done by statutory instrument (decree) and would be subject to consent provisions by the devolved legislatures. The concession was undermined, however, by the new clause specifying exactly how the consent provisions were to work. If the devolved legislatures agreed to the orders, they would go ahead; if they refused consent, the orders would go ahead; and if they did not state an opinion, they would go ahead. While in a strict legal sense, this would not change anything, as Westminster has always claimed the right to proceed without consent under the Sewel Convention, the provision, like the Supreme Court judgment, served to emphasize that such conventions really count for nothing. It thus represents a setback for the federalizing trend that has been under way since the devolution settlement of 1999, which itself was reaffirmed by the unionist parties in the Scotland Act of 2016.

\section{Disintegration}

21 Immediately after the vote, the Scottish First Minister declared that another Scottish independence referendum was likely in order to keep Scotland in the EU. In March 2017 the Scottish Parliament, with a pro-independence majority consisting of the SNP and Greens, passed a resolution supporting another referendum. They claimed a mandate for this on the grounds that the SNP manifesto for the 2016 Scottish elections had said that there would not be a new independence referendum unless there was a material change of circumstances such as Scotland being taken out of the EU against its will. This is exactly what had happened. The unionist response was that the 2014 referendum result was still binding.

Independence in Europe, however, does not provide a simple answer. Since the mid-1980s the SNP have argued for independence-in-Europe as a way of softening the impact of secession, avoiding hard borders and providing an external support system for a small independent nation; other European nationalist movements make the same argument. Yet an integral part of the argument was that, with the Kingdom also inside the EU, there would be no hard border between them and no obstacle to trade. With Scotland in the EU and the UK outside, there would be a hard economic border. This is a vital matter, as Scotland does about four times as much trade with the rest of the UK as with the EU 27. 
ere was some debate at the time of the 2014 referendum about whether an independent Scotland would be allowed into the EU. José Manuel Barroso, then President of the European Commission, pronounced that it would be "difficult if not impossible". There was, however, no legal basis for this and most academic observers agreed that as, under the Edinburgh Agreement, an independent Scotland would be recognized by the United Kingdom, there was no reason for any other state to refuse recognition. ${ }^{6}$ Given that it was a liberal democracy and market economy already meeting the acquis communautaire, there were no grounds for excluding it. The Spanish Foreign Minister even conceded that Spain would follow the UK line ${ }^{7}$ and in 2017 his successor made the point explicit. ${ }^{8}$ The difficulties, rather, hinge on the process of accession and whether Scotland would inherit the UK terms of membership. It is unlikely that the EU would simultaneously negotiate Brexit and Scottish accession but, if the latter had not been agreed by the time the UK leaves the EU, Scotland could be left in limbo.

Another possibility is that Scotland could opt for membership of the European Economic Area (EEA). In that case, it would be within the Single Market but not within the customs union and so able also to negotiate a free trade agreement with the United Kingdom. It would also be outside the Common Fisheries Policy, a contentious point in Scotland. On the other hand, negotiating EEA membership might be no less complex than getting into the EU and it would mean that Scotland, like Norway, would have to accept Single Market policies without having a role in making them.

Brexit did not, as widely expected, produce an increase in support for independence, which remained at the same level (around 45 per cent) as it had since the Scottish independence referendum. As noted above, not all SNP voters support the EU and around a third of them had voted for Brexit. Taking votes for independence and for Brexit together, the result is as shown in Table 2.

Table 2. Support for EU and independence in Scotland

\begin{tabular}{|l|l|l|}
\hline & Yes independence & No independence \\
\hline Remain & 27 & 34 \\
\hline Leave & 17 & 21 \\
\hline TOTAL & 44 & 55 \\
\hline
\end{tabular}

Chris Prosser and Ed Fieldhouse, A tale of two referendums - the 2017 election in Scotland, British Election Study, http://www.britishelectionstudy.com/bes-findings/a-tale-of-two-referendums-the-2017election-in-scotland/\#.WeoCaDb907M

It is clear from this that there is no combination of positions on the independence and European questions that commands majority support in Scotland. The difficulty was illustrated, and compounded, when the UK Government called a general election in 2017. The SNP, which had won 56 of the 59 Scottish seats in 2015, remained the largest party but was reduced to 35 seats. The Conservatives experienced a significant revival, gaining twelve seats at the expense of the SNP, largely because of the latter's proEuropean stance. With thirteen seats at Westminster (following their second place in 
the Scottish elections of 2016), the Scottish Conservatives became a significant force in Scottish politics for the first time in thirty years.

Finally, the Scottish Government would require the consent of the UK Government in order to repeat the 2014 referendum. The UK Government response was not to rule out an independence referendum in Scotland but to declare that this is not the time. It thus once again side-stepped the issue of principle of whether Scotland has a right to selfdetermination, while retaining control of the issue. The Scottish Government could perhaps organize its own referendum on a question that could be within the law but this would carry little conviction. The unionists could simply boycott the campaign and the vote, thus depriving it of legitimacy. In the event, the fall in support for the SNP at the 2017 UK General Election removed the prospect of an imminent independence referendum.

\section{Reconfiguration}

This leaves the option of differentiation for the devolved territories. There have been efforts to find a new middle ground, both between nationalism and unionism and between remaining in and leaving the EU, by allowing parts of the UK to remain in the $\mathrm{EU}$ at least for some purposes. Yet differentiation is more difficult in relation to $\mathrm{EU}$ membership than it is within the United Kingdom itself since the EU is based on law and on political compromises that are difficult to unwind.

The Scottish Government proposed that, if the UK is going to leave the EU, including the Single Market, then Scotland would remain in the Single Market even as England and Wales left. ${ }^{9}$ This would give it a status analogous to that of the European Economic Area (EEA); indeed Scotland might formally become part of the EEA. As with the EEA, agriculture and fisheries would be excluded. If the UK were to leave the EU customs union (as it declared it would), Scotland would also leave, remaining in a customs union with the UK. This would allow it to avoid tariffs and rules of origin on trade in goods between Scotland and the rest of the UK and thus obviate the need for a physical border. There would be full access to the Single Market in services and provision for the free movement of workers between Scotland and the EU-27. All parties in the Scottish Parliament favour free movement and there is a broad consensus in favour of immigration, in contrast to England. Scotland would participate in European social provisions, academic exchange and research and in aspects of EU Justice and Home Affairs policies.

These proposals are legally and technically feasible, although they do pose challenges. Being in a customs union with the UK and a Single Market with the EU could be complex. Retaining a customs union with the UK could remove the need for physical checks on goods traded between Scotland and England. There would, however, need to be rules governing the treatment of goods entering the UK from EU countries, depending on whether they were destined for Scotland or for England and Wales (we leave Northern Ireland aside here as it too might have a differentiated settlement). The Scottish Government concedes that there would have to be certification as to the final point of sale of such goods. There would also have to be rules of origin if intermediate goods were passing through England and Wales en route for Scotland. 
31 Kingdom, allowing its transformation into a form of asymmetrical and quasi-federal state embedded in a complex system of shared sovereignty and interdependence. This has accorded with the aspiration of the largest number of Scots. While Westminster never formally surrendered sovereignty either to the EU or to Scotland, practice and convention meant that in effect power was shared and constitutional clashes were avoided. There has been little litigation about Scotland's powers and almost all the cases have involved European law rather than the domestic settlement. This is difficult to sustain in the context of Brexit. A paradoxical effect of the Brexit referendum, which was ostensibly about reasserting the sovereignty of the British Parliament, was in fact to undermine that sovereignty and both Conservative and Labour parties insisted that the supreme rule was the will of the people, before which Parliament must bow. Yet once the popular will is introduced, the question arises of who are the people and whether there is just one demos in the United Kingdom. The Scottish vote to remain was substantially larger than the overall UK majority to leave, and arguably provides a quite separate mandate. 

Rights Act, which incorporates the European Convention on Human Rights into UK law. Instead, there would be a British Bill of Rights. Proponents of this idea seemed initially unaware that the ECHR was also incorporated into the law of the devolved territories, so that their devolution statutes would also have to be amended. Yet that provision has served an important stabilizing role by separating nationality from rights and providing a nationally neutral framework for ruling on them. When this has been pointed out, opponents of the ECHR have fallen into confusion, some of them suggesting that the British Bill of Rights might be confined to England and others just wanting to go ahead anyway. The proposal has been put on hold during the debate on membership of the EU but is likely to resurface in the future and will put a further strain on the union. Once again, it is unionists who are putting the union at risk.

travails of the UK Government following the triggering of Article 50 in March 2017 demonstrated that the idea of sovereignty is much more complex than supporters of Brexit supposed. By the summer of 2018, the UK Government had retreated on their sweeping proposals to take back powers from the devolved legislatures, while not conceding on their right to do so. At the European Elections in May 2019, the SNP ran on a strongly pro-European platform, joining the Liberal Democrats and Greens in calling for a second EU referendum to reverse Brexit. These pro-EU parties gained over 60 per cent of the vote while the Brexit Party (which led in England and Wales) was far behind at less than 15 per cent. There is also some evidence that the SNP has lost many of its former Leave voters and so has a more coherent pro-Europe base. None of this, however, was enough to create a clear majority for independence.

\section{Conclusion}

At the time of writing, the Brexit saga has a long way to run but one thing is clear sovereignty in the old sense is more of a slogan than a practical reality in a complex and interdependent world. Neither the Scottish independence referendum of 2014 nor the Brexit referendum of 2016 could have brought back the old nation-state. Whatever happens, Scotland, as Leruez showed all those years ago, remains a nation, a distinct society and, increasingly a self-governing community. It remains without a state because statehood itself no longer means what it once did but its future is unknown.

\section{BIBLIOGRAPHY}

Keating, Michael, Plurinational Democracy. Stateless Nations in a Post-Sovereignty Era (Oxford, Oxford University Press, 2001).

Keating, Michael, The Independence of Scotland. Self-Government and the Shifting Politics of Union (Oxford, Oxford University Press, 2009).

Revue Française de Civilisation Britannique, XXIV-4 | 2019 
Keating, Michael, ‘The European Question', in Michael Keating (ed.), Debating Scotland. Issues of Independence and Union in the 2014 Referendum (Oxford, Oxford University Press, 2017).

MacCormick, Neil, Questioning Sovereignty. Law, State and Nation in the European Commonwealth, (Oxford, Oxford University Press, 1999).

Prosser, Chris and Fieldhouse, Ed, A tale of two referendums - the 2017 election in Scotland, British Election Study, http://www.britishelectionstudy.com/bes-findings/a-tale-of-tworeferendums-the-2017-election-in-scotland/\#.WeoCaDb907M

Scottish Government, Scotland's Place in Europe (Edinburgh, Scottish Government, 2016).

UK Government, Legislating for the United Kingdom's withdrawal from the European Union, 2017.

UK Supreme Court, Judgment on the application of Miller and another) (Respondents) $v$ Secretary of State for Exiting the European Union (Appellant) (London, UK Supreme Court, 2017).

\section{NOTES}

1. Neil MacCormick, Questioning Sovereignty. Law, State and Nation in the European Commonwealth (Oxford, Oxford University Press, 1999); Michael Keating, Plurinational Democracy. Stateless Nations in a Post-Sovereignty Era (Oxford, Oxford University Press, 2001).

2. Neil MacCormick, Questioning Sovereignty. Law, State and Nation in the European Commonwealth (Oxford, Oxford University Press, 1999).

3. Michael Keating, The Independence of Scotland. Self-Government and the Shifting Politics of Union (Oxford, Oxford University Press, 2009).

4. UK Supreme Court, Judgment on the application of Miller and another (Respondents) $v$ Secretary of State for Exiting the European Union (Appellant) (London, UK Supreme Court, 2017).

5. UK Government, Legislating for the United Kingdom's withdrawal from the European Union, 2017.

6. Michael Keating, 'The European Question', in Michael Keating (ed.), Debating Scotland. Issues of Independence and Union in the 2014 Referendum (Oxford, Oxford University Press, 2017).

7. Ibid.

8. Quoted in $A B C, 02.04 .2017$.

9. Scottish Government, Scotland's Place in Europe (Edinburgh, Scottish Government, 2016).

\section{ABSTRACTS}

Since 1999 Scotland has a devolved Parliament and Government. The European Union provided an important framework. EU membership reinforces ideas of shared and divided sovereignty. Through the European Single Market it secures the internal market of the United Kingdom itself. The EU, together with the European Convention on Human Rights, directly applicable in Scotland, separates rights from nationality. Brexit thus destabilizes the domestic devolution settlement. 
Depuis 1999, l'Écosse dispose d'un Parlement et d'un gouvernement autonome. L'Union européenne fournit un cadre externe pour cette dévolution du pouvoir. L'appartenance à l'Union renforce le concept de souveraineté partagée, longtemps présent dans la pensée politique écossaise. Le marché unique européen assure le marché intérieur du Royaume-Uni. Le droit communautaire, avec la Convention européenne des droits de l'homme (applicable directement en Écosse) définit des droits humains sans référence à la nationalité. La sortie du Royaume-Uni de l'Union européenne déstabilise donc le système.

\section{INDEX}

Mots-clés: Écosse, dévolution, Europe, Brexit.

Keywords: Scotland, devolution, Europe, Brexit

\section{AUTHOR}

\section{MICHAEL KEATING}

Michael Keating is Professor of Politics at the University of Aberdeen and Director of the Centre on Constitutional Change based at the University of Edinburgh. He is currently directing a major project on the effects of Brexit on the devolution settlements in the United Kingdom. 